Vol. 6, No. 1, 2020

\title{
Viktor Proskuryakov \\ PARTICIPATION OF LECTURERS AND STUDENTS
OF LVIV ARCHITECTURAL SCHOOL IN PRAGUE QUADRENNIAL 2019
}

\author{
Professor of the Department of Architectural Environment Design \\ Lviv Polytechnic National University, Lviv \\ e-mail: Viktor.I.Proskuriakov@lpnu.ua \\ orcid: 0000-0003-1022-8984
}

Received: 27.05.2020 / Revised: 11.06.2020 / Accepted: 11.06.2020

(C) Proskuryakov V., 2020

https://doi.org/10.23939/as2020.01.117

Abstract. The article describes the participation of the lecturers and the students of the Lviv Architectural School, the Department of Architectural Environment Design of Lviv Polytechnic National University in the events of the Prague Quadrennial 19, a global exhibition held in the capital of The Czech Republic, June 6-16, 2019.

Key words: exhibitions of countries and regions, students, museum, exhibitions of theatrical design and space, at the events of the Prague Quadrennial.

\section{Problem statement}

After the Prague Quadrennial 2015, the first joint participation of Ukrainian set designers and architects in the world exhibitions dedicated to theatrical art in the section "Education", the lecturers of the Department did not plan to continue working in that direction yet. However, exactly at that time, in Prague, the organizers of the PQ15 granted the first Ukrainian exhibition the status of "National" and invited its designers to participate in the next one, in 2019. This appreciation of the Ukrainian exhibition was possible thanks to the participation of colleagues from the Theater School of Ryerson University (Toronto, Canada). The Department and its administration put most of their efforts and money into the organization of the exhibition formed from the creative works of a world-renowned set designer Ye. Lysyk, the projects, and the realizations of the theatrical architecture of the students, the lecturers, and the doctoral students. Canadian Professors P. Bosyy and Sh. Dolgoy became the main coordinators of the second transatlantic seminar on theatrical art, at which 19 speeches were delivered on the topics of theatrical architecture, set design, technology, technology, history, etc. At that time, the exhibition materials and the Ukrainian seminar reports were mostly dedicated to the phenomenon of creativity of the artist Ye. Lysyk, who would have turned 85 in 2015 (Sodja Lotker, 2015, p. 10).

When the organizers of the forthcoming PQ19 exhibition invited the academics of the Department to take part in the event, the curator of the First Ukrainian National Exhibition at the forthcoming Quadrennial, Professor P. Bosyy insisted that the Department not only design an exhibition pavilion but also take part in a wider range of events in Lviv.

\section{Objective of the article}

The paper aims to present the unique events of the PQ19 in which the Lviv Architectural School participated to gain experience in designing space for presenting national achievements in theatrical culture.

\section{Results and discussions}

Unlike the Prague Quadrennial 2015, during which the academic staff and the students of the Department of Architectural Environment Design participated in the Second Transatlantic Seminar on theatrical art and organized the collection of materials, designed and produced the exhibition in the section "Education" in Kafka's House, new participation in the Quadrennial had more vectors of activity (Exhibition of Countries \& Regions, Fragments, 2019, p. 26, 58). First, the academics together with the students of the Department, designed, made and assembled on the premises of the main exhibition pavilion of the PQ19, "Industrial Palace", and site No 13 for the First Ukrainian National Exhibition at the Prague Quadrennial, their own and also the First Pavilion where the decisions for the best 5 set designs in the Ukrainian puppet theaters, speeches by seminar leaders of the Fourth Transatlantic Seminar on theatrical art, discussions, and exchange of experience on theatrical issues, etc were planned. The idea of space construction, the organization of acting, and aesthetical design decision for the architecture of the pavilion was implemented as the space for the "Kupala drama" - a performance that takes its origin and was developed in ancient times in Ukraine. After Professor V. Proskuryakov reconstructed the general appearance of the Kupala Theater space, modernized it in terms of the materials, structures, technical and technological equipment and agreed the scale of the pavilion with the parameters of the space provided by the organizers of the PQ19 in spring 2019, the pavilion was built in Lviv, delivered and assembled in Prague on the eve of the Quadrennial opening. Secondly, six scientists of the Department prepared reports and delivered speeches at the Fourth Transatlantic Seminar on theatrical art, namely Professor V. Proskuryakov, Ph.D. Arch. B. Hoy and Z. Klymko, postgraduate students and scientists Yu. Bohdanova, I. Kopylyak, 
Yu. Filipchuk and also the participants from Canada, namely Professor P. Bosyy, students Alessya Urbani and Andrew Nasturtsio, and a reputable stage designer Nino Gunia-Kuznetsova from Georgia. This seminar was not large-scale in terms of the number of presentations made compared to the Second Transatlantic Seminar on theatrical art during the PQ15. At that time, 19 speeches were delivered, while in 2019 - 10. The exhibition space of the Ukrainian exposition in 2015 was designed at the Department of Architectural Environment Design as a space of a new type of exposition. It was designed as the theater, a stage, a lecture-hall, an educational and design studio, an architectural and theatrical studio. Among all the other events, the most notable was the Second Transatlantic Seminar on theatrical art, during which the professors, the lecturers, the postgraduate students, and the students from Lviv and Toronto made their speeches. The range of research topics of the presentations was extremely broad, and while the participants from Ukraine focused on theatrical architecture - "Designing theatrical architecture by the lecturers and the students of the Lviv Architectural School", "Architecture of national theaters in Ukraine and areas of its development", "Designing the landscape theaters of Ukraine", "Forming architecture of spaces for the accumulation, storage, restoration and display of the scenographic artworks "(the case of "Lysyk's Houses"), etc., the participants from Canada mainly presented reports on theatrical design. These reports were dedicated to the creative process of making costume designs for performances, stage design for musicals, and dramatic performances; organization of stage lighting; specificity of theatrical process organization in Canada... But the 2019 Seminar had its unique features. Three languages of the seminar - Ukrainian, English and Georgian - became official. Moreover, the topics of the reports were more diverse and apart from reports on theatrical architecture and set design, reports on costume design, spaces for performances in historic Ukrainian cultural and educational buildings, in natural landscapes, outside the walls of theater buildings were presented. In addition to the speakers, the seminar was attended by so many visitors who took an active part in the discussions that the coordinator of the First Ukrainian National Exhibition, Professor P. Bosyy, moved it from the pavilion to the stage and to the ground floor of the summer stage opposite the left wing of the "Industrial Palace" (Fig. 1).

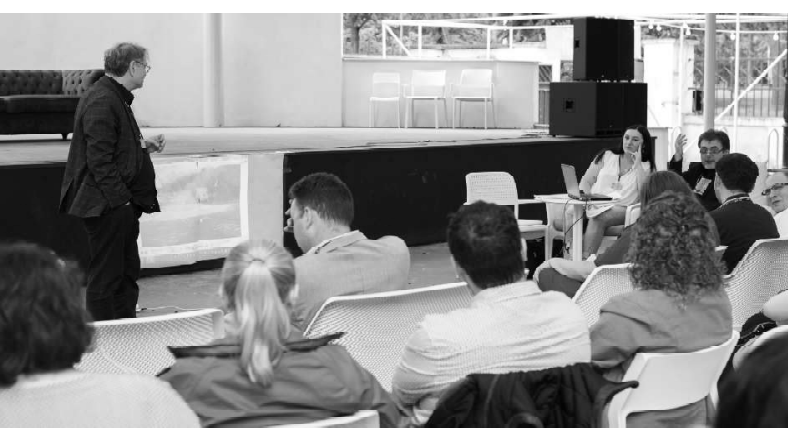

Fig. 1. Photo of the Fourth Transatlantic Seminar on theatrical art on the summer stage opposite the left wing of the main exhibition space PQ19 of the Industrial Palace. (From the archive of the Department of Architectural Environment Design)

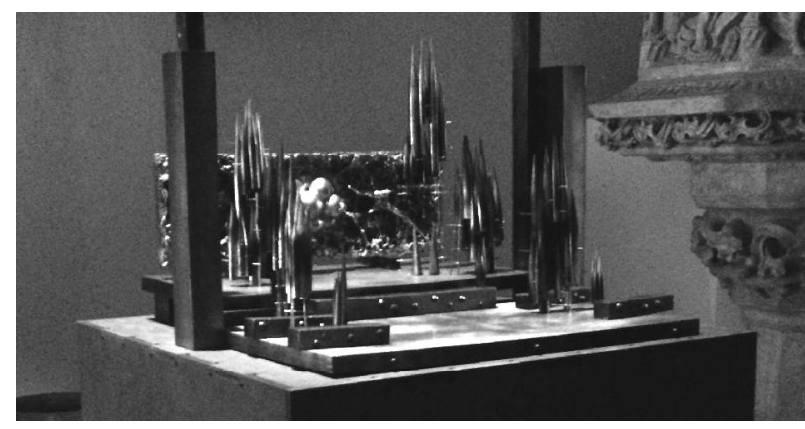

Fig. 2. Photo of the model of the set design by Ye. Lysyk for the ballet "Creation of the World" exhibited in the palace

"Lapidarium" (From the archive of Professor V. Proskuryakov)

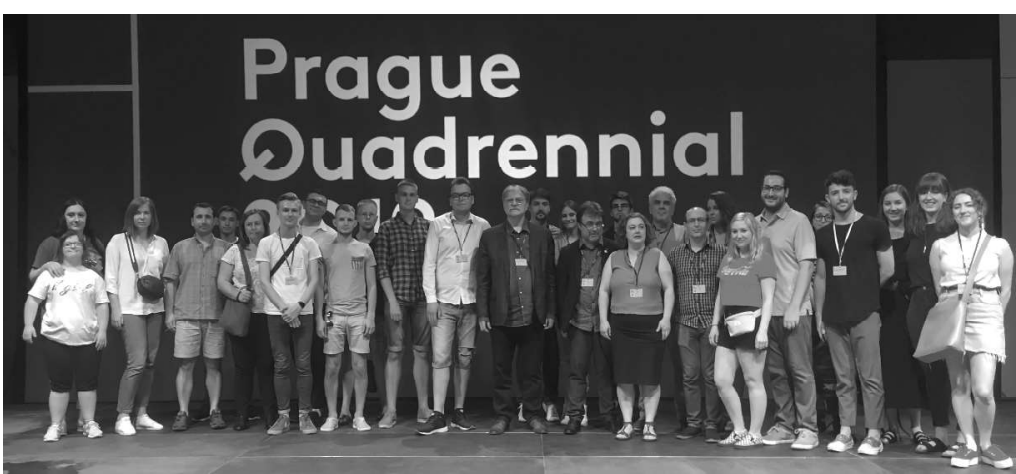

Fig. 3. Delegation of the Department of Architectural Environment Design with the Canadian and Georgian colleagues at the Krizik Pavilione Palace after the PQ Talks on June 7, 2019 at 2:00 pm. (From Professor V. Proskuryakov's archive)
Third, Professor V. Proskuryakov spoke at the highest level of the Quadrennial conference - the PQ Talks - history, theory, collaboration, making a joint presentation of the theme "The results of the collaboration of architects, technologists and performers" with the report "Specificity of collaboration between architects and theater designers". It was based on the results of the UkrainianCanadian student project seminar in Lviv in 2017 on the renovation of the main hall of the First Academic Building of Lviv Polytechnic National University with the expansion of theater and performance, cultural and educational functions.

The conceptual foundation of the seminar was formed by Professors V. Proskuryakov from Lviv Polytechnic National University, Lviv, Ukraine, and P. Bosyy and Sh. Dolgoy from Ryerson University, Toronto, Canada. P. Bosyy was the moderator of the event. Besides Professor V. Proskuryakov, A. Gilbert (Canada), O. Ryabchenko (Ukraine) also made presentations and Sh. Dolgoy presented a video report. One of the most important tasks of the Department was to deliver from Lviv and install the set design model for the ballet "Creation of the World" in one of the halls of the Lapidarium Pavilion at the PQ19. It is a model by the prominent Ukrainian stage artist, the lead artist of Lviv National Theatre of Opera and Ballet Yevgen Lysyk. In total, Ye. Lysyk designed three models for the ballet "Creation of the World". The first one was designed in 1972 in Lviv for the Bolshoi Theater (music by A. Petrov, ballet master M. Zaslavskyy). The second was designed in 1976 for the Opera and Ballet Theater in Minsk, Belarus (ballet master. V. Yelizaryev). And the third one was made in 1986 for 
I. Franko Theater of Opera and Ballet of Lviv (ballet master G. Yusupov). This third version of the model was a complete renovation of the previous ones and was installed in Prague in 2019. The presented model was a great success among other exhibits in this pavilion - models, drawings, costumes, etc. created by set designers who made a significant contribution to the development of theatrical culture - Ming Cho Lee from the USA, Alexander Lisianskyy from Israel, Iva Nemtsov, from The Czech Republic, Francis O'Connor from Ireland, Juan Gomez from Spain and many other artists, including Pamela Howard. The interest in the work of Ye. Lysyk was undoubtedly stimulated by a bio-bibliographic index published in English. It was compiled by the joint efforts of Professor V. Proskuryakov, Candidate of Architecture Z. Klymko, and the wife of the artist Oksana Lysyk-Zinchenko. The translation of the text was carried out by Professors P. Bosyy and I. Derkach. It was published by the "Silver Word" publishing house and Lviv Polytechnic Publishing House (V. Proskuryakov, O. Zinchenko, Z. Klymko, 2015, 68 p.). It was exhibited on the model podium. Also Ye. Lysyk's work benefitted from the very site offered by the organizers for its presentation. The tectonics of the model seemed to resonate with the architectural molds from the Prague churches displayed on the walls of the Lapidarium in which it was located (Fig. 2). Another important event, organized by the Department at the Prague Quadrennial, was a scientific and educational excursion of the students, the bachelor students, the master students, the postgraduate students and the graduates in 2019 who together with the academic staff also attended the world exhibition and participated in all the above-mentioned events. The exhibition was attended by those who took part in the preparation of the exposition and the First Ukrainian National Exhibition pavilion, the preparation of video materials for the Fourth Transatlantic Seminar, etc., and also those whose academic topic in recent years has been the theatrical art. It is reflected in the academic planning of all levels - semester, research, competition, Bachelor's, and Master's theses.

\title{
Conclusions
}

1. The participation of the academic staff and the students of the Department of Architectural Environment Design in the events such as the Prague Quadrennial is extremely useful not only for the lecturers, but also for the students, because they acquire and use the unique special knowledge they will need in their professional activity and, in particular, in designing different forms of theatrical and performance objects.

2. Applying the experience of the Prague Quadrennial in the Department of Architectural Environment Design of Lviv Polytechnic National University it is possible to include the specializations "Set design architecture" and "Architectural and scenographic aspects of urban development", which are already taught in other architecture schools within the specialty "Architecture and Urban Planning".

3. The participation of a large group of representatives of the Lviv Architectural School, in total 19 academics, researchers and students in the PQ19 events, proved that communication at the forums of such high rank is an extremely effective form of both rapid acquisition of quality knowledge in the field of theatrical arts and integration of participants in common European cultural space (Fig. 3).

\section{References}

Sodja Lotker. 2015. Shared Space Music Weather Polities. B: L. Cepcova, S. Lotker, D.Parizkova, O. Svoboda, Prague Quadrennial of Performance Design and Space. Prague. 8.06.2015-18.06.2015. Arts and Theatre Institute. p. 10.

Exhibition of Countries \& Regions, Fragments. 2019. Prague Quadrennial of Performance Design and Space. Program brochure PQ19 imagination, transformation, memory. Prague. 6.06.2019 - 16.06.2019. Arts and Theatre Institute. p. 26, 58.

V. Proskuryakov, O. Zinchenko, Z. Klymko. 2015. Yevhen Lysyk: Bibliography \& Cataloguing in Teatrical, Time, Spase, Scenography and Architecture. Lviv: "Sribne slovo". 68 p.

\section{Віктор Проскуряков}

\author{
Професор кафедри дизайну архітектурного середовища, \\ Науіональний університет “Львівська політехніка", Львів \\ e-mail: Viktor.I.Proskuriakov@lpnu.ua \\ orcid: 0000-0003-1022-8984
}

\section{УЧАСТЬ ВИКЛАДАЧІВ І СТУДЕНТІВ ЛЬВІВСЬКОӤ АРХІТЕКТУРНОӤ ШКОЛИ В ЗАХОДАХ ПРАЗЬКОГО КВАДРІЕНАЛЕ 2019 РОКУ}

\footnotetext{
Анотація. У публікачії висвітлено низку унікальних заходів PQ19, в яких взяла участь Львівська архітектурна школа для набуття досвіду в творенні середовища для презентачій науіональних досягнень у театральній культурі. По-перие, викладачі, при залученні студентів кафедри, запроєктували, виготовили і змонтували в Празі в “Промисловому палачі", для Периої української науіональної виставки Перший павільйон для показу вирішення 5 кращих суенографій украӥнських лялькових театрів; для виступів з доповідями референтів; для бесід і обміну досвідом. По-друге, шість науковчів кафедри підготували доповіді $i$ виступили на IV Трансатлантичному семінарі з театрального мистечтва; професор Проскуряков B., Ph.d.Arch. Гой Б. і Климко 3.; аспіранти і науковиі Богданова Ю., Копиляк І., Філіпчук Ю. А. також учасники з Канади: професор П. Босий, студенти Урбані і Настурчіо; та Н. Гунія Кузнєчова з Грузії. По-третє, професор В. Проскуряков виступив на найвищому рівні конференцї Квадрієнале - “РQ Таlks - історія, теорія, співробітничтво" у спільній презентачії теми "Результати співпраці архітекторів, технологів $і$ виконавиів" з доповіддю “Особливості співпрауі архітекторів і театральних дизайнерів", яка спиралася на результати студентського українсько-канадського проєктного семінару у Львові в 2017 рочі. Й одним із найважливіших заходів були доставка зі Львові і встановлення в одному із залів павільйону "Лапідаріум" макету вистави-балету видатного украйнського художсика-суенографа С. Лисика "Сотворння Світу" науково-освітні екскурсії студентів, бакалаврів, магістрів, аспірантів на виставчі, і участь ӥх у конференуіях всіх рангів.

Ключові слова: виставки крайн і регіонів, студентські, музейні, виставки театрального дизайну $і$ простору в заходах Празького квадріснале.
} 